\title{
Relationship between Class Size and Academic Achievement
}

\author{
Laraib $^{1}$, Saira Ijaz Ahmad ${ }^{2}$, Mobeen-ul-Islam ${ }^{3}$
}

\begin{abstract}
Class size can be defined as the total number of students' in a course or classroom, taught by an instructor throughout the year (Blatchford, 2003) and it is one of the major indicator that influence the Students' Academic Achievement (Adunola, 2013; Vandenberg, 2012; Kornfeld, 2010). The main objective of the study was to find out "The Relationship between Class Size and Students' Academic Achievement". The nature of the study was co-relational and population of the study was students' of $5^{\text {th }}$ Grade. The study was delimited to the District Gujrat and twenty five public schools were randomly selected. A check list was developed by reviewing the literature then it was validated through expert's opinion. The data were collected from the Heads of the selected schools. Data were analyzed through SPSS version 21. Findings of the study revealed that Class Size of $5^{\text {th }}$ Graders at Elementary Schools were more than the average Class Size determined by Tomlisnson (1988). Moreover, it revealed, negative and strong correlation between class Size and Academic Achievement scores in general at both boys and girls Elementary Schools.
\end{abstract}

Keywords: Class Size; $5^{\text {th }}$ Grader; Academic Achievement

\section{Introduction}

Class Size is characterized as the number of Students' in a class with one instructor. Tomlisnson (1988) identified that there are four different types of class: a) Ideal Classes (10-12 pupils for each instructor), b) Small Classes (1317 pupils' for each instructor), c) Standard Classes (22-25 pupils' for each instructor), d) and General Classes (22-25 pupils' with an instructor and a fulltime guest instructor). Class size affects the performance of both the teacher and the students' by the number of ways. Finn et al. (2003) exposed that the teacher can easily engage pupils in small classes and the pupils can also minimize their disturbing attitude in small classes as compared to the class where the number of the Students' are extended.

According to the Caplin's Dictionary of Psychology (1965) Academic

\footnotetext{
${ }^{1}$ M.Phil Scholar, Department of Education, University of Gujrat

${ }^{2}$ Lecturer, Department of Education, University of Gujrat. Email: saira.usman@uog.edu.pk

${ }^{3}$ Assistant Professor, Department of Education, University of Gujrat
} 
Achievement has been characterized as the level of fulfillment of proficiency in scholastic act as assessed by instructor or through institutionalized accomplishment tests. Academic Achievement is essential because it makes pupil or person ready for future professions. Academic Achievement helps the teachers to shape the minds of the pupils and promote them in next grade. In this study the researcher studied the relationship between the Class Size and Students' Academic Achievement and the difference between the Academic Achievement of boys and girls students of grade $5^{\text {th }}$. There are many factors that affect the students' Academic Achievement for example Gender (Chambers and Schreiber, 2004); Socio Economic Status of the Students (Capraro \& Wiggins, 2000), Parental Education (Ceballo, McLoyd \& Toyokawa, 2004), and Home Environment (Barnard, 2004; Henderson, 1988; Shumox \& Lomax, 2001) and Class Size (Blatchford, 2003).

Class Size plays a major role in the academic career of the pupil as well as the teacher and school also. It is an important variable that directly and indirectly affects the students' Academic Achievement. If the number of the pupils would be increased in the class then the Achievement level of Students' will be decreased (Biddle, B. J., \& Berliner, D. C. 2002). There are many researches on An Analysis of The Relationship between Class Size and Academic Performance of Students (ADUNOLA, 2013),Class Size and students' Academic Achievement (Vandenberg, 2012) and The Effects of Class Size on Student Academic Achievement in a Rural State (Kornfeld, 2010).

This study would be helpful for the heads of the schools, teachers, Students, curriculum developer and also for the policy makers. Head of the school would divide the class into the small groups according to the average Class Size. The teacher would plan different activities in the class for the Students related to his/her topic. He/she can easily give the feedback and proper guidance for the students. Students would easily ask the questions from their teacher and the relation between the teachers to student and student to student would be stronger as compared to the large class size. The curriculum experts would plan and design different activities, It would be helpful for policy maker to refine the existing educational policies.

\subsection{Objectives of Study}

Major objectives of the study were:

1 Find the class size of $5^{\text {th }}$ graders in Elementary Schools.

2 Determine the achievement level of $5^{\text {th }}$ graders in Elementary Schools.

3 Compare the class size of $5^{\text {th }}$ graders between the boys and girls in Elementary Schools. 
4 Compare the mean achievement score of $5^{\text {th }}$ graders between the boys and girls in Elementary Schools.

5 Determine the relationship between class size and achievement of $5^{\text {th }}$ graders in Elementary Schools.

\subsection{Research Questions}

1. What is the class size of $5^{\text {th }}$ grade in Elementary Schools?

2. What is the class size of $5^{\text {th }}$ grade in boys Elementary Schools?

3. What is the class size of $5^{\text {th }}$ grade in girls Elementary Schools?

4. What is the mean achievement score of $5^{\text {th }}$ grade in Elementary Schools?

5. What is the mean achievement score of boys 5th grade in Elementary Schools?

6. What is the mean achievement score of girls 5th grade in Elementary Schools?

7. Do 5th grade class size differ between boys and girls in Elementary School?

8. Do 5th grade academic achievement differs between boys and girls in Elementary Schools?

9. Do class size and achievement scores of 5th graders in Elementary Schools correlated significantly?

\section{Literature Review}

Hanushek (1999) suggested that in the established elementary school level class size can be defined as classroom is the duty of one Instructor/Teacher in an independent class room, number of pupils is the main duty of one teacher in a class within a year. The small number of Students e.g. 11 will be considered a small Class Size as well as large number of Students e.g. 20 or additional Students will be considered as large Class Size. The size of class influences the teaching. If a class is small in size then teacher may spend extra time with each student as compare to large Class Size. In smaller classes the teacher may face less challenge as compare to the large classes as: a) to organize the class, b) to direct and evaluate and, c) to plan activities. Teachers feel more stress in large Class Size. And in smaller classes teacher can easily judge the challenges and provide better suggestions and guideline to his/her Students. A teacher can be well aware about his/her Students needs and can maintain good relations with them.

Classroom administration is an issue of that class in which the number of Students' is large. The absence of suitable physical space is a component influencing guideline, and as indicated by Blatchford et al. (2007), having pupils' closer to one another in physical vicinity escorts classroom 
administration issues because of the instructor's failure to face the challenging Students large size class.

To maintain a methodical and safe learning situation, instructors of a large number of pupils' are less inclined to utilize inquiry-based study facilities (Deutsch, 2003). A deficiency of physical space deprive continue the teachers from having the capacity to utilize a different types of instructional methods and to adjust the learning environment to tackle in a better way the issues of the pupils' (Deutsch, 2003; Blatchford et al., 2007).

Need for using class time for the treatment of the pupils' misbehavior could influence on pupils' Achievement also be a reason aligned with ever-increasing number of Students' (Blatchford et al., 2007). Cakmak (2009) indicated that large size classes have more cases of pupils' bad behavior and less Academic Achievement because of instructional time being utilized for classroom administration. Adding to this study with respect to Class Size with classroom administration were investigated that how the collaborations between the instructors and the pupils' are influenced by larger number Students. North Carolina recommended that Small Classes (15 or less pupils) helped instructors to resolve discipline issues through the individual connections they found themselves able to build up with their pupils.

Instructors expressed that in small classes, they found themselves able to interact more with pupils' and maintain discipline issues from happening (Egelson et al., 1996). Increased the number of the pupils' in the classroom influences the instructors associations towards pupils and also disturb pupil to pupil communications (Blatchford et al., 2003a; Blatchford et. al., 2007).

Small Classes enhance teacher and Students' collaborations. Instructors in small classes have the capacity to give learners more instructional criticism (Blatchford et al., 2003a; Pedder, 2006). Day after day interaction with student allowed instructors to evaluate the instructional and necessities of their students'. Having the capacity to have quality associations with their pupils is a vital part of small Size classes as this encourages the instructor to arrange and execute instructional exercises (Blatchford et al., 2003a). The utilization of direct guideline of an individual is an effect instructor and Students connections that absolutely influences the instructional exercises. Blatchford et al., 2005; Cakmak, 2009; Blatchford et al., 2003 studied that instructors give additional time for immediate direction of individual student in small classes.

Hedges and Stock (1983) proposed that: a. Small Classes are critical for extended Student Achievement. b. Students with inferior pedagogic have a more learning ability/capacity as compare to larger classes c. Lesser classes can 
emphatically influence the Academic Achievement of financially or socially burdened Students.

Black and William (1998) explained that Achievement is the definite body of information. This gives remedial information of students. Achievement is able to expose capability of Students as well as the results may be used to predict the future action. There were several factors effecting on the students' Academic Achievement. Goddard (2003) defined that the atmosphere as well as the individual qualities of the learner's one assumed a vital part in their Achievement. This societal help is an essential part for the achievement of completing objectives of pupils in school. Furstenberg and Hughes (1995) explained that society, social structure and association of children's extend the rate of Academic Achievement. Gender, orientation, plus father's profession are important contributors to pupils accomplishment (McCoy, 2005; Peng and Hall, 1995).

Parental education has an important impact on the pupil's Academic Achievement. The gender of the Students' emphatically influences their Academic execution. The girls do better as compare to the boys, normally hard work to get good marks at school (Ceballo, McLoyd \& Toyokawa, 2004). Home environment of pupils' also influences the student's Academic Achievement of the pupils (Marzano, 2003). Other demographic elements, the impacts of Socio Economic Status are salient predominant on the level of Achievement (Capraro, R., Capraro, M., and Wiggins, 2000). This can be considered in a variety of techniques. It is frequently figured by taking a parental instruction, occupation, wage, and offices utilized by people independently or all in all.

\subsection{Population and Sample}

\section{Research Methodology}

Researcher targeted the $5^{\text {th }}$ graders enrolled in elementary schools situated in the jurisdiction of Tehsil Gujrat. Reason of selecting the $5^{\text {th }}$ graders was that $5^{\text {th }}$ grader is the terminal stage of primary education. It is significant in the sense as the learner at this stage must learn the basic literacy and numeracy skills. It is necessary to ensure the learning of these desired skills by the teacher and the larger no. of students in a class may suffer from effective learning. Accessible population for the researcher was those elementary schools situated in the jurisdiction of four Marakaz i.e. Markaz East (Boys'\& Girls') and Markaz West (Boys'\& Girls') in Tehsil Gujrat. Sample of the study was selected using two stage random sampling technique. Firstly four Cluster Training and Support Centers (CTSC) out of five CTSCs situated from four above mentioned Marakaz. Secondly twenty five elementary schools were selected randomly from 
three selected CTSCs. List of the schools were taken from District Training and Support Centre (DTSC) Gujrat. Each Markaz has 65 schools and researcher selected 20\% schools from each Markaz.

\subsection{Research Instrument}

Two main variable of the study were the Class Size and Academic Achievement. To check the Class Size the check list was developed by the researcher. The indicators of the checklist were (a) school type, (b) sections, (c) strength of the Students' and (d) gender. For the Academic Achievement the result of the Students' of $5^{\text {th }}$ grade was taken by the Pec annual results 2014.

\subsubsection{Validation of Research Instrument}

Checklist items were validated through expert's opinion. In the light of feedback received from the experts, the check list was finalized.

\subsection{Data Collection}

The researcher personally visited the selected schools and a meeting was organized with the head of the school. Head teacher was informed about the visit. $\mathrm{He} / \mathrm{she}$ was asked to fill in the checklist. Direction was given to the head about the filling of the checklist. They were asked that the information provided was kept in confidential and just used for researcher purpose.

\section{Data Analysis}

Data were tabulated in SPSS (version21). Mean and standard deviation was calculated to describe the sample of the study. Pearson-r was calculated to find out the relationship between the Class Size and Students' academic achievement. Independent Sample t-test was used to find out the differences of Class Size and Academic Achievement between boys and girls of elementary schools.

\subsection{Results of Study}

What is the Class Size of $5^{\text {th }}$ Grade at Elementary Schools?

Table 4.1

Mean Class Size of $5^{\text {th }}$ Grade at Elementary Schools

\begin{tabular}{llll}
\hline & N & Mean & SD \\
\hline Class Size & 25 & 37.15 & 19.55
\end{tabular}

Table 4.1 shows that Class Size of $5^{\text {th }}$ grade in elementary schools is $(\mathrm{M}=37.15, \mathrm{SD}=19.55)$ whereas average Class Size should be 25 (Tomlisnson, 1988)). It is concluded that existing Class Size of $5^{\text {th }}$ grade in elementary schools greater than average Class Size. 
What is the Class Size of $5^{\text {th }}$ Grade of Boys at Elementary Schools?

Table 4.2

Class Size of $5^{\text {th }}$ Grade of Boys at Elementary Schools

\begin{tabular}{llll}
\hline & $\mathrm{N}$ & Mean & SD \\
\hline Class Size & 9 & 45.44 & 22.55
\end{tabular}

Table 4.2 shows that Class Size of $5^{\text {th }}$ grade in boys' elementary schools is $(\mathrm{M}=37.15, \mathrm{SD}=22.55)$ whereas average Class Size should be 25 . It is concluded that existing Class Size of $5^{\text {th }}$ grade in boys elementary schools greater than average Class Size.

What is the Class Size of $5^{\text {th }}$ Grade at Girls Elementary Schools?

Table 4.3

Class Size of $5^{\text {th }}$ Grade at Girls' Elementary Schools

\begin{tabular}{llll}
\hline & $\mathrm{N}$ & Mean & SD \\
\hline Class Size & 16 & 32.48 & 16.66 \\
\hline
\end{tabular}

Table 4.3 shows that Class Size of $5^{\text {th }}$ grade in girls' elementary schools is $(\mathrm{M}=32.48, \mathrm{SD}=16.66)$ whereas average Class Size should be 25. It is concluded that existing Class Size of $5^{\text {th }}$ grade in girls elementary schools greater than average Class Size.

What is the Mean Achievement Score of $5^{\text {th }}$ Grade at Elementary Schools?

Table 4.4

Mean Achievement Score of $5^{\text {th }}$ Grade at Elementary Schools

\begin{tabular}{llll}
\hline & $\mathrm{N}$ & Mean & SD \\
\hline Academic Achievement & 25 & 186.88 & 70.30 \\
\hline
\end{tabular}

Table 4.4 shows that Mean Achievement Score $(M=186.88, S D=70.30)$ of $5^{\text {th }}$ grade in elementary schools. The mean achievement score was obtained from 500. It shows that $5^{\text {th }}$ graders from elementary schools of Tehsil Gujrat are below average.

What is the Mean Achievement score Boys' of $5^{\text {th }}$ Grade at Elementary schools?

Table 4.5

Mean Achievement Score Boys' of $5^{\text {th }}$ Grade at Elementary Schools

\begin{tabular}{llll}
\hline & $\mathrm{N}$ & Mean & SD \\
\hline Academic Achievement & 9 & 132.11 & 58.84 \\
\hline
\end{tabular}


Table 4.5 shows that Mean Achievement Score of boys' $(\mathrm{M}=132.11, \mathrm{SD}=58.84)$ of 5 th grade in elementary schools. The mean achievement score was obtained from 500. It shows that 5th graders from elementary schools of Tehsil Gujrat are below average.

What is the Mean Achievement Score Girls' of 5th Grade at Elementary Schools?

Table 4.6

Mean Achievement Score Girls' of $5^{\text {th }}$ Grade at Elementary Schools

\begin{tabular}{llll}
\hline & $\mathrm{N}$ & Mean & SD \\
\hline Academic Achievement & 16 & 217.96 & 57.00 \\
\hline
\end{tabular}

Table 4.6 shows that Mean Achievement Score of girls' $(M=217.96, S D=57.00)$ of 5 th grade in elementary schools. The mean achievement score was obtained from 500. It shows that 5th graders from elementary schools' of Tehsil Gujrat are below average.

Does 5th Grade Class Size differ between boys' and girls' at Elementary Schools?

Table 4.7

Comparison of $5^{\text {th }}$ Graders Class Size between Boys' and Girls' Elementary Schools

\begin{tabular}{|c|c|c|c|c|c|c|}
\hline Variables & $\mathrm{N}$ & Mean & $\mathrm{SD}$ & $\overline{\mathrm{Df}}$ & t-value & Sig. \\
\hline Boys & 9 & 4 & 22.55 & 23 & 1.07 & 0.114 \\
\hline Girls & 16 & 32.48 & 16.66 & & & \\
\hline \multicolumn{7}{|c|}{$\begin{array}{l}\text { Table } 4.7 \text { shows that t-value }(23)=1.64 \text { is not significant because } \\
\mathrm{p}=0.114>\alpha=0.05 \text {. This shows that boys' }(\mathrm{M}=45.44, \mathrm{SD}=22.55) \text { and girls } \\
(\mathrm{M}=32.48, \mathrm{SD}=16.66) 5^{\text {th }} \text { classes in elementary schools do not differ in class } \\
\text { size. } \\
\text { Does } 5^{\text {th }} \text { Grade Academic Achievement differ between Boys' and Girls' at } \\
\text { Elementary Schools? } \\
\text { Table } 4.8 \\
\text { Comparison of } 5^{\text {th }} \text { Grader's Academic Achievement between Boys' and Girls' } \\
\text { Elementary Schools }\end{array}$} \\
\hline Variables & $\mathrm{N}$ & Mean & $\mathrm{SD}$ & $\overline{\mathrm{Df}}$ & t-value & Sig. \\
\hline $\begin{array}{l}\text { Boys } \\
\text { Girls }\end{array}$ & $\begin{array}{l}9 \\
16\end{array}$ & $\begin{array}{l}132.11 \\
217.96\end{array}$ & $\begin{array}{l}58.84 \\
57.00\end{array}$ & 23 & -3.56 & .002 \\
\hline
\end{tabular}


Table 4.8 shows that t-value (23) $=-3.56$ is not significant because $\mathrm{p}=.002<\alpha=0.05$. Table 4.6 shows that $\mathrm{t}$-value $=1.64$ is not significant because $\mathrm{p}=0.114>\alpha=0.05$. This shows that boys' and girls' $5^{\text {th }}$ classes in elementary schools differ in Academic Achievement

Girls' Academic Achievement (M=217.96, S.D. $=57.00)$ is better than boys'

Academic Achievement $(\mathrm{M}=132.11$, S.D. $=58.84)$.

Do Class Size and Achievement Scores of $5^{\text {th }}$ graders at Elementary Schools correlated significantly?

Table 4.9

Correlation between Class Size and Mean Achievement Scores of $5^{\text {th }}$ at Elementary schools

\begin{tabular}{cccccc}
\hline Variables & $\mathrm{N}$ & Mean & SD & $\mathrm{R}$ & Sig. \\
\hline Mean & 25 & 186.88 & 70.30 & -0.542 & $0.005^{* *}$ \\
Class Size & 25 & 19.58 & 19.58 & & \\
\hline$* \mathrm{P}<.05,{ }^{* *} \mathrm{p}<.01$ & & & &
\end{tabular}

Table 4.9 shows that value of Pearson $\mathrm{r}=-0.542$ is significant because $p=0.005<\alpha=0.01$. This shows that there exist strong and negative correlation between class size and Academic Achievement of $5^{\text {th }}$ graders in elementary schools.

\section{Discussion}

Diane Whitmore Schanzenbach (2014) reviewed the literature and reported that class size is significant predictor of students Cognition, Affective and Psychomotor outcomes. The study analyzed the relationship between class size and students' academic achievement. Strong and negative correlation was found between class size and academic achievement of elementary schools. The results of the study were similar to the research studies conducting to find out the relationship between class size and students' academic achievement (Mersch, 2012, ADUNOLA, 2013 and BAKASA, 2011).The results of the study were contradicted to the study as reported by linnerbrink (2013) in which no significant relationship was found between class size and students' academic achievement in elementary grades in LOWA.

\section{Conclusions}

1. More crowdie $5^{\text {th }}$ classes were found both boys' and girls' in elementary schools.

2. Academic Achievement of both boys' and girls' 5thgraders in elementary schools were found below to average.

3. No difference was found in class size between boys' and girls' elementary 
schools.

4. Negative and strong correlation was found between class and Academic Achievement of elementary schools.

\section{Recommendations}

1 Class size may be settled up to the average class size at elementary schools.

2 Employers should be recruited the teachers keeping in mind Class Size or Students' teachers ratio.

3 More teachers training institutions should be established for the production of trained elementary teachers.

4 More studies should be conducted at various levels elementary, secondary as well as higher level.

5 Teachers should be trained in both pedagogy as well as content to make the Students' performance better.

\section{References}

Achilles, C. M., Finn, J. D., \& Bain, H. P. (1998). Using class size to reduce the equity gap. Educational Leadership, 40-43. doi:0.3102/01623737021002097.

Adunola, O. (2013). An Analysis of the Relationship between Class Size and Academic Performance of Students", EgoBooster Books, Ogun State, Nigeria.

Barnard, W. M. (2004). Parent involvement in elementary school and educational attainment. Children and Youth Services Review, 26, 39- 62.

Biddle, B. J., \& Berliner, D. C. (2002, February). Small class size and its effects. Educational Leadership, 59(5), 12-23.

Blatchford, P., Edmonds, S., \& Martin, C. (2003b). Class size, pupil attentiveness and peer relations. Journal of Educational Psychology, 73(1), 15-36.

Blatchford, P., Bassett, P., Goldstein, H., \& Martin, C. (2003a). Are class size differences related to pupils' educational progress and classroom processes? Findings from the institute of education class size study of children aged 57years. British Educational Research Journal, 29(5), 709-730. doi: 10.1080/0141192032000133668 
Blatchford, P., Bassett, P., \& Brown, P. (2005). Teachers' and pupils' behavior in large and small classes: A systematic observation study of pupils aged 10/11years. Educational Psychology, 97(3), 454-467.

Blatchford, P., Russell, A., Bassett, P., Brown, P., \& Martin, C. (2007). The effect of class size on the teaching of pupils aged 7-11 years. School Effectiveness and School Improvement, 18(2), 147-172. doi: $10.1080 / 09243450601058675$.

Cakmak, M. (2009). The perceptions of student teachers about the effects of class size with regard to effective teaching process. The Qualitative Report, 14(3), 395-408. Retrieved from http://www.nova.edu/ssss/QR/QR14-3/cakmak.pdf/

Egelson, P., Harman, P., \& Achilles, C.M. (1996). Does class size make a difference? Recent findings from state and district initiatives. Tallahassee,

Capraro, M. M., Capraro, R. M., \& Wiggins, B. B. (2000). An investigation of the effect of gender, socioeconomic status, race and grades on standardized test scores. Paper presented at the meeting of the Southwest Educational Research Association, Dallas, TX.

Ceballo, R., McLoyd, V., \& Toyokawa, T. (2004). The influence of neighborhood quality on adolescents' educational values and school efforts. Journal of Adolescent Research, 19(6), 716-739.

Deutsch, F. M. (2003). How small classes benefit high school Students'. NASSP Bulletin, 87(635), 35-44.

Finn, J. D., Pannozzo, G., \& Achilles, C. M. (2003). The "why's" of class size: Student behavior in small classes. Review of Educational Research, 73(3), 321-368.

Furstenberg, F. F., \& Hughes, M. E.(1995). Social capital and successful development among at-risk youth. Journal of Marriage and the Family, 57, 580-592.

Goddard, R. D. (2003). Relational networks, social trust, and norms: A social 
capital perspective on Students'" chances of academic success. Educational Evaluations \& Policy Analysis, 25, 59-74

Hanushek, E. A. (1999). The evidence on class size. In S. Mayer \& P. Peterson (Eds.), Earning and learning: How schools matter. Washington, DC: Brookings Institution Press.

Hattie, J. (2005, May). The paradox of reducing class size and improving learning outcomes. Keynote presentation at the International Conference on Class Size, University of Hong Kong.

Hirschfeld, P. (2009, June 12). Too many schools, too few students, says ed chief. The Times Argus.

Hanushek, E. A. (1986). The economics of schooling: Production and efficiency in public schools. Journal of Economic Literature, 24, 1141-1177. Retrieved from http://www.jstor.org/stable/2725865.

Henderson, A. T. (1988). Good news: An ecologically balanced approach to academic improvement. Educational Horizons, 66(2), 60-67.

Kornfeld, M. (2010) The Effects of Class Size on Student Academic Achievement in a Rural State. Ph.D thesis, The Faculty of the Graduate College, The University of Vermont.

Marzano, R. J. (2003). What works in schools: Translating research into action? Parenting, 2(2), 127-150. Retrieved from http://pdonline.ascd.org/pd_online/whatworks/marzano2003_ch13 .html and adolescent outcomes.

Shumox, L., \& Lomax, R. (2001). Parental efficacy: Predictor of parenting behavior

Pedder, D. (2006). Are small classes better? Understanding relationships between small class size, classroom processes and pupils' learning. Oxford Review of Education, 32(2), 231-234. doi: 10.1080/03054980600645396. 
Peng, S. S., \& Hall, S. T. (1995). Understanding racial-ethnic differences in secondary school science and mathematics achievement (NCES No. 95710). Washington DC: U.S. Department of Education.

Trawler, P. R. \& Knight, P. T. 2002. Exploring the implementation gap: Theory and practices in change intervention in higher education policy and institutional change: intentions and outcomes in turbulent environments. Buckingham, U.K: Open University press.)

Tomlinson, T. (1988). Class size and public policy: Politics and panaceas. Washington, DC: Office of Educational Research and Improvement.

Tomlinson, T. (1990). Class Size and Public Policy: The Plot Thickens, Contemporary Education, pp. 17-23.

Vandenberg, K. C. (2012). Class size and student's Academic Achievement, Electronic Theses \& Dissertations Jack N. Averitt College of Graduate Studies (COGS). Georgia Southern University, Digital Commons @Georgia Southern 